\title{
Effects of human disturbance on the mongoose lemur Eulemur mongoz in Comoros: implications and potential for the conservation of a Critically Endangered species
}

\author{
Bakri Nadhurou, Roberta Righini, Marco Gamba, Paola Laiolo \\ Ahmed Ouledi and Cristina Giacoma
}

\begin{abstract}
The decline of the mongoose lemur Eulemur mongoz has resulted in a change of its conservation status from Vulnerable to Critically Endangered. Assessing the current threats to the species and the attitudes of the people coexisting with it is fundamental to understanding whether and how human impacts may affect populations. A questionnaire-based analysis was used to study the impact of agriculture and other subsistence activities, and local educational initiatives, on lemur abundance, group size and composition in the Comoros. On the islands of Mohéli and Anjouan we recorded 214 lemurs in 63 groups, the size and composition of which depended both on environmental parameters and the magnitude and type of anthropogenic pressure. There was no evidence of an impact of anthropogenic disturbance on abundance. In contrast, group size and composition were sensitive to human impacts. The most important threats were conflicts related to crop raiding, as well as illegal capture and hunting. The promotion of educational activities reduced the negative impact of hunting and illegal activities. These results highlight a need for urgent conservation measures to protect the species.
\end{abstract}

Keywords Crop raiding, environmental education, lemur, plantation, population size, primate, recruitment

To view supplementary material for this article, please visit http://dx.doi.org/10.1017/So030605315000897

\section{Introduction}

$\mathrm{M}$ ore than half of the extant primate species are threatened by anthropogenic factors such as the

Bakri Nadhurou (Corresponding author), Roberta Righini, Marco Gamba, Paola Laiolo* and Cristina Giacoma Department of Life Sciences and Systems Biology University of Torino, Via Accademia Albertina, 13, 10123 Torino, Italy. E-mail bakrinad@yahoo.fr

Ahmed Ouledi Université des Comores, Faculté des Sciences et Techniques, Union des Comores

${ }^{*}$ Also at: Research Unit of Biodiversity, University of Oviedo, 33600 Mieres, Spain

Received 27 February 2015. Revision requested 31 March 2015

Accepted 21 July 2015. First published online 3o October 2015 conversion of forests into farmland, habitat loss and fragmentation, hunting for meat, and direct persecution as agricultural pests (Schwitzer et al., 2014). Shortage of essential resources, poverty and food insecurity often accentuate anthropogenic pressures. Human well-being is dependent on biodiversity (Naeem et al., 2012) but many activities deemed indispensable for human subsistence lead to biodiversity losses (Díaz et al., 2006; Reuter et al., 2014). Damage to crops, livestock or human life by wildlife provides sufficient motivation for people to eradicate potential animal competitors (Ogada et al., 2003) and to reduce the quantity and quality of natural habitats on private and communal lands (Albers \& Ferraro, 2006).

Lemurs comprise $>20 \%$ of all primate species and $>30 \%$ of extant primate families (Mittermeier et al., 2010). All lemurs are endemic to Madagascar, which is a biodiversity hotspot (Ganzhorn et al., 2001) but also one of the least economically developed regions (World Bank, 2013). There are numerous challenges to in situ conservation of lemurs, and plans to reduce threats require full understanding of distribution, population size and, for social species, group organization. However, there is relatively little information available for the majority of threatened primates (Mittermeier et al., 2010).

Our aim was to update information on the conservation status of the mongoose lemur Eulemur mongoz and the local threats to the species, which occupies a small geographical range in the north-western Malagasy forests and on the Comoros islands of Anjouan and Mohéli (Mittermeier et al., 2010). Despite legal protection its status in Madagascar has worsened since the 1990s; it was categorized as Vulnerable in 1996 but its status was changed to Critically Endangered (Andriaholinirina et al., 2014), mainly as a result of habitat loss and hunting pressure.

In the Comoros there is no recent information available on this species (but see Tattersall, 1998) and, although genetic data support the hypothesis that the mongoose lemur was introduced there (Pastorini et al., 2003), assessing its status on these islands is important because the population may represent a valuable genetic reservoir in view of the critical status of the species on mainland Madagascar.

To contribute to the planning of sustainable conservation activities, we surveyed the Comorian forests where 
E. mongoz had been recorded previously, and estimated its relative abundance, group size and variation in group composition. We also investigated its habitat requirements, focusing in particular on the impact of forest degradation and human disturbance. We interviewed members of local communities to clarify the type and magnitude of existing conflicts in terms of food security, hunting for food or defending fruit and crops, as well as activities affecting habitat quality for the species, such as logging, slash and burn agriculture and livestock grazing. We tested the relative importance of potential environmental and anthropogenic predictors, taking into account habitat characteristics (including elevation) as drivers of food availability for the species, the impact of agriculture or charcoal production as major anthropogenic disturbance factors, and the potentially positive effects of education programmes.

\section{Methods}

\section{Data collection}

We conducted transect surveys (following Salmona et al., 2014) at seven sites on the island of Mohéli and eight on Anjouan (Fig. 1) during 2 August-30 October 2012. During the day two people travelled once and in one direction only along beaten paths, roads and cattle trails, walking quietly at c. $1 \mathrm{~km}$ per hour. We found no wild lemurs on Grande Comore (Supplementary Material 3).

For indices of relative abundance we used group encounter rate and the number of individual males, females and young per $\mathrm{km}$. For group structure parameters we recorded group size (the total number of individuals) and composition (total number of males, females and young), sex ratio and recruitment rate (number of young/number of females). We identified males by their rufous cheeks and beard, which are invariably white in females (Mittermeier et al., 2010). We considered as young all individuals aged $<1$ year, which are easily distinguishable by their smaller size. As transects were well spaced and each was travelled only once, in one direction, we can reasonably argue that each recorded group comprised a unique set of individuals in the majority of observations. Moreover, considering the fusion-fission nature of many primate social groups, even if certain individuals were detected on more than one transect, the probability of detecting a group (the unit of our analysis) composed of exactly the same individuals on several transects was low. Accordingly, groups were treated as independent units in all analyses. We considered that lemur detectability did not vary significantly among habitats (Supplementary Material 1), and that group size and abundance could thus be adequately compared across sites.

We considered one continuous variable (elevation) and two categorical variables (island and habitat types) as

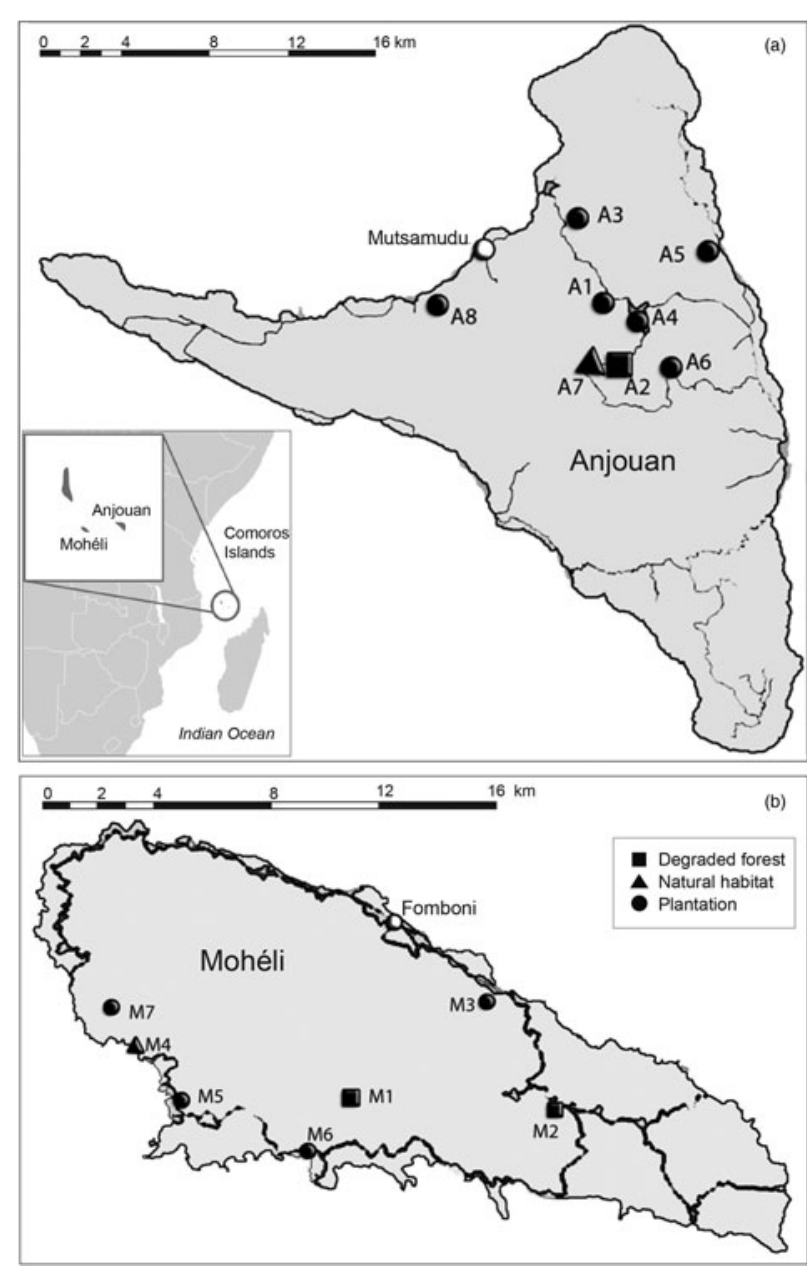

FIG. 1 Survey sites on the Comoros islands of (a) Anjouan and (b) Mohéli.

predictors of the abundance and group composition of E. mongoz. At each sampling site we categorized habitat type as natural forest, degraded forest or plantation, on a gradient of increasing human impact (following ECDD, BCSF \& Durrell, 2013; Supplementary Material 1). Human impact was qualitatively estimated by four predictors, describing the presence or absence of captive animals in nearby villages (B. Nadhurou, pers. obs.), direct evidence of logging, charcoal production, and livestock grazing within each sampling area. We considered whether a survey area was involved in the Progeco environmental education programme conducted by the Marine National Park of Mohéli or by the Ouallah Association (the latter at sites M1, M4, M6 and M7; Table 1; Supplementary Material 2).

\section{Statistical analysis}

We used Mann-Whitney and Kruskal-Wallis tests to explore variations in relative abundance and group structure (group size, group composition, sex ratio and recruitment parameters) along with geographical and environmental 
TABLE 1 The 15 sites on Mohéli and Anjouan islands (Fig. 1) where surveys were carried out for mongoose lemurs Eulemur mongoz, with village, municipality, prefecture, geographical coordinates, elevational range and habitat type.

\begin{tabular}{|c|c|c|c|c|c|c|}
\hline Site & Village & Municipality & Prefecture & $\begin{array}{l}\text { Geographical } \\
\text { coordinates }\end{array}$ & $\begin{array}{l}\text { Elevational } \\
\text { range }(\mathrm{m})\end{array}$ & Habitat type \\
\hline \multicolumn{7}{|l|}{ Mohéli } \\
\hline M1, Ouallah 2 & Ouallah-Mirereni & Nioumachoua & Nioumachoua & $12^{\circ} 20^{\prime} 32^{\prime \prime} \mathrm{S} 43^{\circ} 40^{\prime} 15^{\prime \prime} \mathrm{E}$ & $43-70$ & $\begin{array}{l}\text { Degraded } \\
\text { forest }\end{array}$ \\
\hline M2, Djandro & Wanani & Wanani & Djandro & $12^{\circ} 20^{\prime} 51^{\prime \prime} \mathrm{S} 43^{\circ} 47^{\prime} 46^{\prime \prime} \mathrm{E}$ & $93-211$ & $\begin{array}{l}\text { Degraded } \\
\text { forest }\end{array}$ \\
\hline M3, Ngnobéni & Djoiézi & Fomboni & Fomboni & $12^{\circ} 18^{\prime} 37^{\prime \prime} \mathrm{S} 43^{\circ} 46^{\prime} 36^{\prime \prime} \mathrm{E}$ & $105-126$ & Plantation \\
\hline M4, Ouallah 1 & Ouallah 1 & Nioumachoua & Mlédjélé & $12^{\circ} 19^{\prime} 23^{\prime \prime} \mathrm{S} 43^{\circ} 40^{\prime} 03^{\prime \prime} \mathrm{E}$ & $18-106$ & Natural forest \\
\hline M5, Ndrodroni & Ndrodroni & Nioumachoua & Mlédjélé & $12^{\circ} 20^{\prime} 46^{\prime \prime} \mathrm{S} 43^{\circ} 40^{\prime} 27^{\prime \prime} \mathrm{E}$ & $112-164$ & Plantation \\
\hline M6, Nioumachoua & Nioumachoua & Nioumachoua & Mlédjélé & $12^{\circ} 21^{\prime} 40^{\prime \prime} \mathrm{S} 43^{\circ} 42^{\prime} 57^{\prime \prime} \mathrm{E}$ & 86-202 & Plantation \\
\hline M7, Miringoni & Miringoni & Nioumachoua & Moimbao & $12^{\circ} 18^{\prime} 20^{\prime \prime} \mathrm{S} 43^{\circ} 38^{\prime} 50^{\prime \prime} \mathrm{E}$ & $53-85$ & $\begin{array}{l}\text { Degraded } \\
\text { forest }\end{array}$ \\
\hline \multicolumn{7}{|l|}{ Anjouan } \\
\hline A1, Gobeni-Msakini & Chandra & Bambao Mtrouni & Ouani & $12^{\circ} 12^{\prime} 10^{\prime \prime} \mathrm{S} 44^{\circ} 27^{\prime} 11^{\prime \prime} \mathrm{E}$ & $27-220$ & Plantation \\
\hline A2, Littoré & Dindri & Bambao Mtrouni & Ouani & $12^{\circ} 13^{\prime} 18^{\prime \prime} \mathrm{S} 44^{\circ} 26^{\prime} 27^{\prime \prime} \mathrm{E}$ & $86-326$ & $\begin{array}{l}\text { Degraded } \\
\text { forest }\end{array}$ \\
\hline A3, Col de patsi & Bazimini & Bazimini & Ouani & $12^{\circ} 11^{\prime} 05^{\prime \prime} \mathrm{S} 44^{\circ} 27^{\prime} 33^{\prime \prime} \mathrm{E}$ & $85-103$ & Plantation \\
\hline A4, Dziani-dzitso & Tsembéhou & Bambao Mtrouni & Ouani & $12^{\circ} 12^{\prime} 31^{\prime \prime} \mathrm{S} 44^{\circ} 28^{\prime} 09^{\prime \prime} \mathrm{E}$ & $67-497$ & Plantation \\
\hline A5, Dongoni & Bambao Mtsanga & $\begin{array}{l}\text { Bambao } \\
\text { Mtsanga }\end{array}$ & Domoni & $12^{\circ} 11^{\prime} 32^{\prime \prime} \mathrm{S} 44^{\circ} 30^{\prime} 23^{\prime \prime} \mathrm{E}$ & $104-556$ & Plantation \\
\hline $\begin{array}{l}\text { A6, } \\
\text { Dzialaoutsounga }\end{array}$ & Tsembéhou & Bambao Mtrouni & Ouani & $12^{\circ} 13^{\prime} 33^{\prime \prime} \mathrm{S} 44^{\circ} 27^{\prime} 08^{\prime \prime} \mathrm{E}$ & $572-752$ & Plantation \\
\hline A7, Dzialandzé & Dindri & Bambao Mtrouni & Ouani & $12^{\circ} 13^{\prime} 34^{\prime \prime} \mathrm{S} 44^{\circ} 26^{\prime} 06^{\prime \prime} \mathrm{E}$ & $430-917$ & Natural forest \\
\hline A8, Mouroijou & Pagé & Mutsamudu & Mutsamudu & $12^{\circ} 12^{\prime} 06^{\prime \prime} \mathrm{S} 44^{\circ} 22^{\prime} 44^{\prime \prime} \mathrm{E}$ & $177-1128$ & Plantation \\
\hline
\end{tabular}

parameters (variation among habitat types, between lowlands and highlands and between Mohéli and Anjouan) and evidence of anthropogenic pressures (effects of illegal activities, logging, charcoal production and livestock grazing). Group size varied with respect to several predictors (see Results), and therefore we explored the combined effect of these predictors using generalized linear models, with type III sums of squares to account for partial effects. We adopted a model selection procedure (Akaike Information Criterion, hereafter AIC; Akaike, 1974) to identify which combination of geographical, environmental and human impact predictors better explained variation in the group structure variables. The continuous variable (elevation) and the categorical variables (habitat type, presence/absence of human impact, and educational activities) were entered as fixed predictors. Residuals of all models were normally distributed (Kolmogorov-Smirnov test, all $\mathrm{P}>0.31$ ). We started with 10 biologically plausible models (on the basis of our preliminary exploration of significant effects and on current knowledge of the species' biology), and combined predictors showing significant effects in multiple models. The models were ranked according to increasing AICc; the best model was established as that having the lowest AIC, and models separated by AIC of $<2$ were considered equally probable as the best model (Burnham \& Anderson, 2002). As an alternative we ran mixed-effect models, entering transect identity as a random term, but the variance attributed to the random factor was null in the majority of models. Accordingly, we present the generalized linear model results only.

\section{Interviews}

We complemented the field data by interviewing 59 local people we met in the survey areas, who agreed to a one-to-one approach. We used semi-structured questionnaires, and BN translated all of them into Comorian to ensure full mutual understanding (Bernard, 2006; details in Supplementary Material 2).

Respondents were categorized according to age (16-30, $30-50$, and $>50$ years old) and occupation (students, teachers, farmers). We used $\chi^{2}$ tests of independence to analyse variation in response frequency. Nonparametric tests were conducted using SPSS v. 21 (IBM, Armonk, USA), and generalized linear models were analysed using $R$ v. 3.1.1 ( $\mathrm{R}$ Development Core Team, 2013; Supplementary Material 2).

\section{Results}

We encountered 214 mongoose lemurs in 63 groups, with a mean group size of $3.40 \pm \mathrm{SD} 1.13$ individuals (range 2-6). We observed 100 males, 96 females and 18 juveniles along $130.50 \mathrm{~km}$ travelled over 95 days (Supplementary Material 3).

The encounter rate over the entire survey area was 1.64 individuals per $\mathrm{km}$ and 0.48 groups per $\mathrm{km}$. The estimated 
TABLE 2 Estimates of the abundance of mongoose lemurs at each of the study sites on Mohéli (M) and Anjouan (A) islands (Table 1; Fig. 1).

\begin{tabular}{|c|c|c|c|c|c|c|}
\hline Site & $\begin{array}{l}\text { Total } \\
\text { survey } \\
\text { length } \\
(\mathrm{km})\end{array}$ & $\begin{array}{l}\text { Groups } \\
\text { per km }\end{array}$ & $\begin{array}{l}\text { Individuals } \\
\text { per km }\end{array}$ & $\begin{array}{l}\text { Males } \\
\text { per km }\end{array}$ & $\begin{array}{l}\text { Females } \\
\text { per km }\end{array}$ & $\begin{array}{l}\text { Young* } \\
\text { per km }\end{array}$ \\
\hline M1 & 5.0 & 0.60 & 3.00 & 1.40 & 1.20 & 0.40 \\
\hline M2 & 12.5 & 0.32 & 1.44 & 0.64 & 0.72 & 0.08 \\
\hline M3 & 6.0 & 0.33 & 1.00 & 0.50 & 0.50 & 0.00 \\
\hline M4 & 29.5 & 0.41 & 1.56 & 0.88 & 0.64 & 0.03 \\
\hline M5 & 7.5 & 0.27 & 0.67 & 0.40 & 0.27 & 0.00 \\
\hline M6 & 2.5 & 0.80 & 4.00 & 2.00 & 1.60 & 0.40 \\
\hline M7 & 9.5 & 0.42 & 1.79 & 0.84 & 0.84 & 0.10 \\
\hline A1 & 6.5 & 0.61 & 2.46 & 0.92 & 1.38 & 0.15 \\
\hline A2 & 3.5 & 0.86 & 2.86 & 1.43 & 1.14 & 0.29 \\
\hline A3 & 9.0 & 0.44 & 1.22 & 0.44 & 0.56 & 0.22 \\
\hline A4 & 10.0 & 0.30 & 0.70 & 0.30 & 0.30 & 0.10 \\
\hline A5 & 9.5 & 0.74 & 1.89 & 0.74 & 0.95 & 0.21 \\
\hline A6 & 4.5 & 0.67 & 2.00 & 0.89 & 0.89 & 0.22 \\
\hline A7 & 7.0 & 0.71 & 1.86 & 0.86 & 0.71 & 0.28 \\
\hline A8 & 8.0 & 0.63 & 1.63 & 0.63 & 0.75 & 0.25 \\
\hline
\end{tabular}

${ }^{\star}$ Individuals $<1$ year old

abundances at the study sites are in Table 2. Encounter rates did not vary significantly across any of the geo-topographical or environmental parameters, forms of anthropogenic pressure, or areas with educational activities (Mann-Whitney and Kruskal-Wallis tests, all $\mathrm{P}>0.061$ ).

In contrast to abundance estimates, variables characterizing group structure varied widely with the predictors. When all predictors were entered in generalized linear models we found that the models that best explained variation in group structure included elevation, habitat type, the occurrence of illegal activities and, in the case of males, the occurrence of educational activities (with a positive effect on numbers; Table 3). In particular, elevation negatively affected group size (estimate $=-0.001 \pm \mathrm{SD} 0.0004, t=-3.82$, $\mathrm{P}=0.0003$ ) and had a stronger impact on the number of females (i.e. steeper slope; estimate $=-0.0009 \pm \mathrm{SD} 0.0002, t$ $=-4.08, \mathrm{P}=0.0001$ ) than on the number of males (estimate $=-0.0007 \pm \mathrm{SD} 0.0002, \quad t=-3.46, \quad \mathrm{P}=0.001$ ). The first 10 models, ranked according to increasing AICc, are in Supplementary Table S1.

Group size tended to be larger in lowlands and on Mohéli (Table 4). With regard to habitat, group size was significantly larger in the degraded forests of Anjouan and Mohéli (Mann-Whitney test: degraded vs natural forest: $U=68.00, \quad \mathrm{P}=0.044 ;$ degraded forest vs plantation: $U=84.50, \mathrm{P}=0.001$; Table 4). The number of males was positively influenced by the absence of charcoal production and livestock grazing and by the occurrence of educational activities (Table 4).

Only 18 (29\%) groups included at least one young. Of these, $22 \%$ consisted of an adult pair, and $78 \%$ consisted
TABLE 3 Results of generalized linear models examining the predictors that significantly affected group size, the number of males (adults and subadults), and the number of females (adults and subadults); generalized linear models were used for 63 survey groups. For comparison with all other models tested see Supplementary Table S1.

\begin{tabular}{lll}
\hline Predictor & $F$ & $\mathrm{P}$ \\
\hline Group size & & \\
Model & & \\
Elevation & $F_{1,58}=14.63$ & $0.0003^{\star *}$ \\
Habitat type & $F_{2,58}=4.20$ & 0.0197 \\
Illegal activities & $F_{1,58}=14.01$ & $0.0004^{\star *}$ \\
No. of males & & \\
Model & & \\
Elevation & $F_{1,57}=1.6744$ & 0.2009 \\
Habitat type & $F_{1,57}=3.6550$ & $0.0321^{\star}$ \\
Illegal activities & $F_{1,57}=2.4932$ & 0.1199 \\
Educational activities & $F_{1,57}=7.1497$ & $0.0098^{\star *}$ \\
No. of females & & \\
Model & & \\
Elevation & $F_{1,58}=16.64$ & $0.0001^{* * *}$ \\
Habitat type & $F_{2,58}=3.64$ & $0.0325^{\star}$ \\
Illegal activities & $F_{1,58}=12.06$ & $0.0009^{\star * *}$ \\
\hline
\end{tabular}

${ }^{\star} \mathrm{P}<0.05 ;{ }^{* * \mathrm{P}}<0.01 ;{ }^{* * * \mathrm{P}}<0.001$

of multi-male and multi-female groups. In general, the recruitment index did not vary with any predictor. The sex ratio varied between habitat types (Kruskal-Wallis test: $\left.\mathrm{H}_{2}=7.566, \mathrm{P}=0.023\right)$ : it was significantly skewed towards females in plantations and in areas with logging activities, whereas in areas associated with educational activities the sex ratio was significantly lower because of the proportionately higher number of males (Table 4 ).

We interviewed 59 local people (58\% on Anjouan and $42 \%$ on Mohéli), including teachers (13\%), students (19\%) and farmers (68\%) (Supplementary Material 2). All respondents declared that they had seen mongoose lemurs but only $34 \%$ had some basic biological information on the species (e. $\mathrm{g}$. that it could be found year-round in the forest). Most people declared that it was possible to see lemurs during the harvest season, when they approach plantations.

A small percentage $(20 \%)$ declared they did not act aggressively towards mongoose lemurs. We found differences between students, farmers and teachers with regard to throwing stones to scare the lemurs away (Fig. 2). Farmers threw stones at lemurs more frequently than students and teachers combined $\left(\chi^{2}=7.83, \mathrm{P}=0.020\right)$.

When we asked whether the lemurs damaged fruit, affirmative answers were given significantly more often by farmers $\left(\chi^{2}=7.74, \mathrm{P}=0.021\right.$; Fig. 2$)$ and by inhabitants of Anjouan $\left(\chi^{2}=4.76, \mathrm{P}=0.029\right)$. Older people also responded in the affirmative at an almost significant higher frequency $\left(\chi^{2}=5.67, \mathrm{P}=0.059\right)$. Inhabitants of Anjouan declared that lemurs damaged 17 tree species of agricultural interest, whereas inhabitants of Mohéli reported only 13 species 
TABLE 4 The parameters describing group size, group composition (number of adult males and females) and sex ratio (female/male), in relation to altitude, island, and presence/absence of anthropogenic impacts. Mann-Whitney $U$ tests and Kruskal-Wallis tests were performed.

\begin{tabular}{|c|c|c|c|c|}
\hline & $\begin{array}{l}\text { Group size } \\
(\text { mean } \pm S D)\end{array}$ & $\begin{array}{l}\text { No. of males } \\
(\text { mean } \pm S D)\end{array}$ & $\begin{array}{l}\text { No. of females } \\
(\text { mean } \pm S D)\end{array}$ & $\begin{array}{l}\text { Female/male ratio } \\
(\text { mean } \pm S D)\end{array}$ \\
\hline \multicolumn{5}{|l|}{ Altitude } \\
\hline Low $(<250 \mathrm{~m})$ & $3.63 \pm 1.11$ & $1.67 \pm 0.66$ & $1.67 \pm 0.59$ & $1.05 \pm 0.54$ \\
\hline $\operatorname{High}(>250 \mathrm{~m})$ & $2.57 \pm 0.66$ & $1.29 \pm 0.47$ & $1.00 \pm 0.39$ & $0.86 \pm 0.31$ \\
\hline Statistics & $Z=3.129^{\star * *}$ & $Z=2.120^{*}$ & $Z=3.648^{\star * *}$ & $Z=0.770$ \\
\hline \multicolumn{5}{|l|}{ Island } \\
\hline Mohéli & $4.03 \pm 1.02$ & $2.07 \pm 0.46$ & $1.76 \pm 0.58$ & $0.87 \pm 0.28$ \\
\hline Anjouan & $2.85 \pm 0.93$ & $1.18 \pm 0.46$ & $1.32 \pm 0.59$ & $1.13 \pm 0.61$ \\
\hline Statistics & $Z=4.115^{\star \star *}$ & $Z=5.728^{\star \star *}$ & $Z=2.880^{\star * *}$ & $Z=2.169^{\star}$ \\
\hline \multicolumn{5}{|l|}{ Habitat type } \\
\hline Degraded forest & $4.29 \pm 0.91$ & $2.00 \pm 0.39$ & $1.93 \pm 0.60$ & $1.01 \pm 0.43$ \\
\hline Natural forest & $3.47 \pm 1.01$ & $1.88 \pm 0.60$ & $1.41 \pm 0.51$ & $0.78 \pm 0.24$ \\
\hline Plantation & $2.97 \pm 1.06$ & $1.25 \pm 0.57$ & $1.41 \pm 0.61$ & $1.13 \pm 0.59$ \\
\hline Statistics & $Z=3.453^{\star * \star}$ & $Z=3.406^{\star * *}$ & $Z=2.494^{*}$ & $Z=2.803^{\star \star \star}$ \\
\hline \multicolumn{5}{|l|}{ Illegal activities } \\
\hline Yes & $2.74 \pm 0.87$ & $1.16 \pm 0.50$ & $1.26 \pm 0.56$ & $1.05 \pm 0.60$ \\
\hline None & $3.68 \pm 1.12$ & $1.77 \pm 0.60$ & $1.64 \pm 0.61$ & $0.99 \pm 0.46$ \\
\hline Statistics & $Z=3.044^{\star * *}$ & $Z=3.540^{\star \star \star}$ & $Z=2.085^{\star}$ & $Z=0.655$ \\
\hline \multicolumn{5}{|l|}{ Logging } \\
\hline Yes & $3.37 \pm 1.18$ & $1.48 \pm 0.62$ & $1.57 \pm 0.65$ & $1.09 \pm 0.54$ \\
\hline None & $3.47 \pm 1.01$ & $1.88 \pm 0.60$ & $1.41 \pm 0.51$ & $0.78 \pm 0.24$ \\
\hline Statistics & $Z=0.384$ & $Z=2.253^{\star}$ & $Z=8.843$ & $Z=2.646^{\star \star \star}$ \\
\hline \multicolumn{5}{|l|}{ Charcoal } \\
\hline Yes & $3.13 \pm 1.01$ & $1.33 \pm 0.55$ & $1.50 \pm 0.63$ & $1.13 \pm 0.61$ \\
\hline None & $3.64 \pm 1.19$ & $1.82 \pm 0.64$ & $1.55 \pm 0.62$ & $0.90 \pm 0.34$ \\
\hline Statistics & $Z=1.680$ & $Z=2.924^{\star * *}$ & $Z=0.124$ & $Z=2.008^{\star}$ \\
\hline \multicolumn{5}{|l|}{ Livestock } \\
\hline Yes & $3.06 \pm 1.00$ & $1.27 \pm 0.52$ & $1.45 \pm 0.62$ & $1.15 \pm 0.61$ \\
\hline None & $3.77 \pm 1.17$ & $1.93 \pm 0.58$ & $1.60 \pm 0.62$ & $0.86 \pm 0.28$ \\
\hline Statistics & $Z=2.406^{\star}$ & $Z=4.128^{\star * *}$ & $Z=0.819$ & $Z=2.219^{\star}$ \\
\hline \multicolumn{5}{|c|}{ Educational activities } \\
\hline Yes & $4.04 \pm 0.98$ & $2.13 \pm 0.46$ & $1.70 \pm 0.47$ & $0.81 \pm 0.23$ \\
\hline None & $3.03 \pm 1.05$ & $1.28 \pm 0.51$ & $1.43 \pm 0.68$ & $1.13 \pm 0.57$ \\
\hline Statistics & $Z=0.378^{\star * *}$ & $Z=4.626^{\star * *}$ & $Z=1.604$ & $Z=2.608^{\star \star \star}$ \\
\hline
\end{tabular}

${ }^{\star} \mathrm{P}<0.05 ;{ }^{* * *} \mathrm{P}<0.001$

affected (see Supplementary Table S2 for a list of the tree species potentially used by lemurs).

Knowledge of the legal protection status of the species was significantly more widespread on Mohéli $\left(\chi^{2}=8.83\right.$, $\mathrm{P}=0.003)$ and, within Mohéli, in areas where educational activities were conducted $\left(\chi^{2}=8.83, \mathrm{P}=0.003\right.$; Fig. 3$)$. Although a proportion of the local population considered the mongoose lemur a threat to crops, people $>50$ years old had a significantly positive attitude towards species protection $\left(\chi^{2}=6.37\right.$, $\mathrm{P}=0.041$ ), as did people living in villages where environmental education activities were conducted $\left(\chi^{2}=8.83, \mathrm{P}=0.035\right)$.

\section{Discussion}

Studies of the impact of global changes on social species have shown more sensitive responses in terms of group size and composition than relative abundance. This is because anthropogenic disturbance tends to affect individual behaviour, movements and social structure (group size, distribution or segregation of the sexes) before any change is detected at the population level (Manor \& Saltz, 2003). We found that male and female distribution followed changes in disturbance levels, as well as the spatial availability of food, with a sex ratio biased towards females in cultivated areas. This is probably because males 'show off when they are with females and infants and are consequently captured more frequently than other group members (B. Nadhurou, pers. obs.). This type of aggressive behaviour is important in primate social organization (Struhsaker, 1998), and its consequences for populations living in humandominated landscapes should be monitored to determine whether it may have a negative demographic impact in the long term. Recruitment is another aspect of the study 

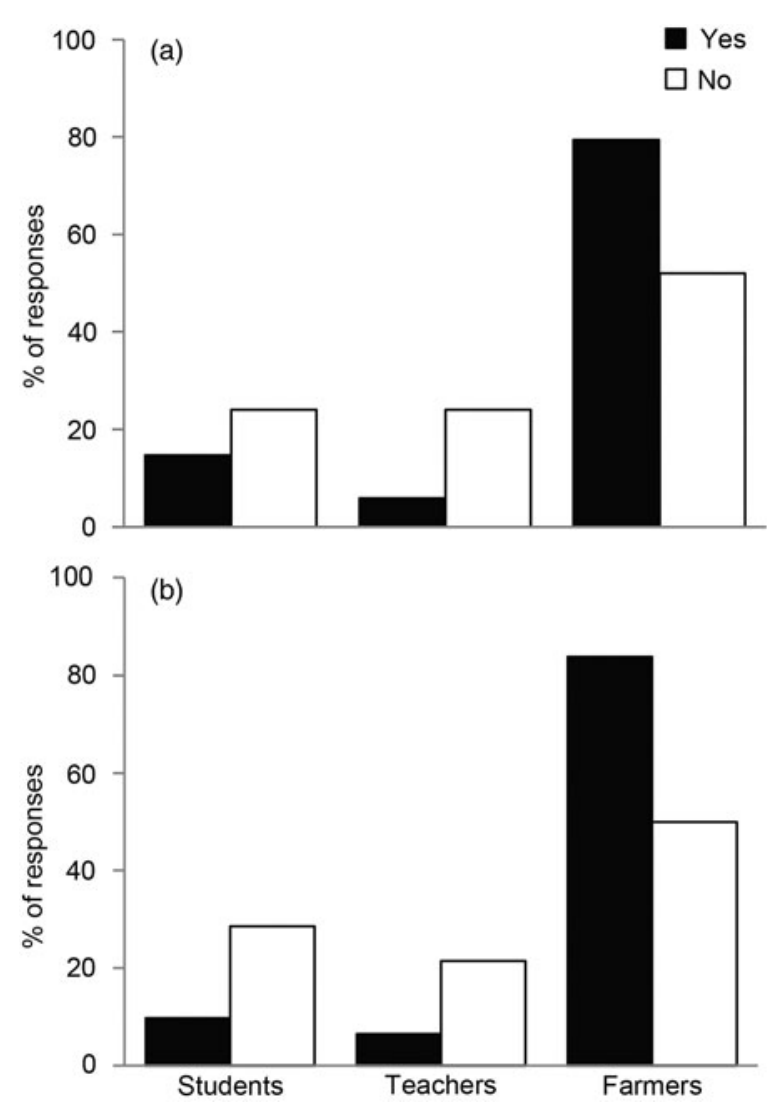

FIG. 2 Proportion of affirmative and negative responses by students, teachers and farmers concerning (a) throwing stones to scare mongoose lemurs Eulemur mongoz, and (b) the perception of lemurs as a threat to fruit crops. Affirmative responses prevailed among farmers, whereas negative responses were more frequent among the two more educated groups.

population that should be monitored; we recorded a recruitment index of $29 \%$, significantly lower than the $48 \%$ recorded by Tattersall (1976). Tattersall (1976) did not quantify recruitment with respect to local anthropogenic pressures and human activities, and therefore we assume that this value corresponds to the best habitats for the species at that time, or the mean value for the islands. However, the human population of the Comoros is increasing by $2.1 \%$ annually, and people's needs are increasing accordingly, with consequent increases in illegal logging, charcoal production, conversion of land to crops, deforestation for firewood and the timber trade, and the use of other forest products (Irwin et al., 2005). These pressures negatively impact wildlife in general (Ganzhorn, 1994) and primate social organization in particular, and one of the first responses is a reduction in group size (Struhsaker, 1998). Mongoose lemurs are also subject to other anthropogenic pressures, such as capture for selling, domestication or consumption. The capture of young lemurs is a long-established practice on Anjouan and Mohéli (Tattersall, 1976) but adults are now also captured. Our low estimate of recruitment is a
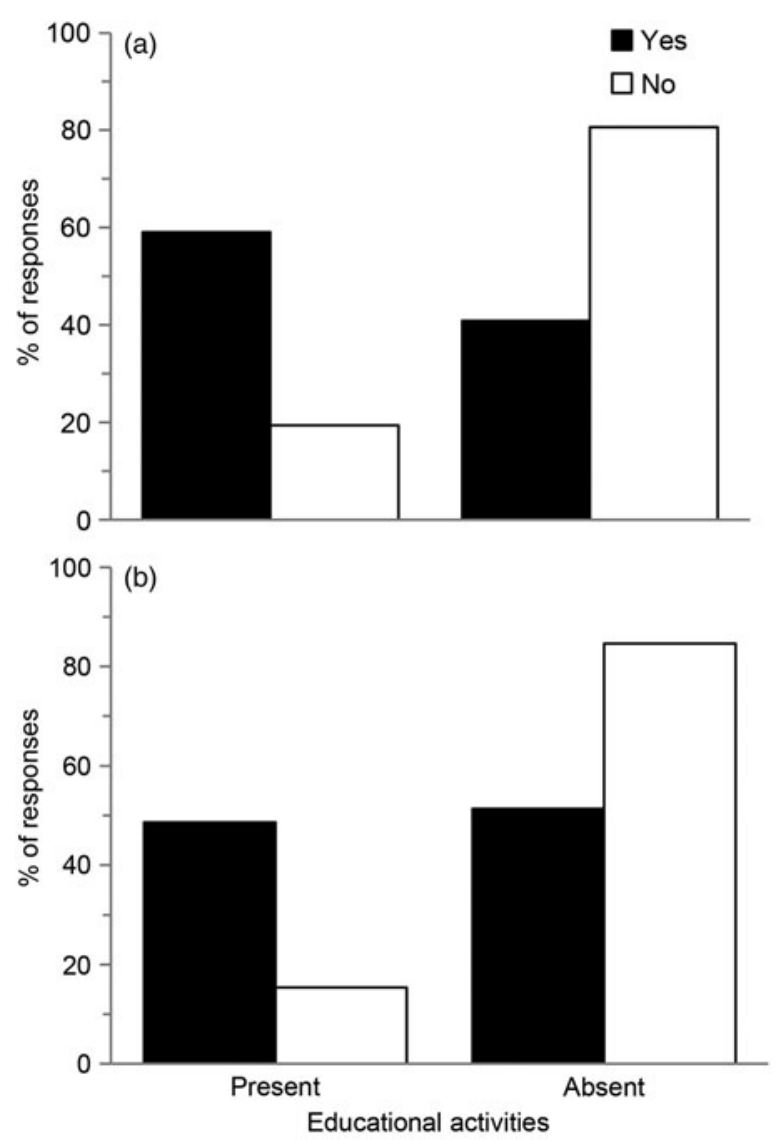

FIG. 3 Proportion of affirmative and negative responses to whether respondents (a) knew that mongoose lemurs are protected by law, and (b) believed protecting the species is important, depending on the presence or absence of educational programmes in their local area.

cause for concern and indicates that urgent measures are needed to identify direct threats and improve the performance and viability of these populations.

On Mohéli mongoose lemurs are not found at elevations $>400 \mathrm{~m}$ but on Anjouan, where the previously reported limit was 600-700 m (Tattersall, 1998), we recorded groups as high as $1,128 \mathrm{~m}$. This mismatch may be a result of sampling biases, although we cannot rule out the possibility that the elevational shift on Anjouan has been induced by human disturbance (or mere presence) in the lowlands, also considering that the attitude towards the species is less benign on this island and the habitat degradation is worse.

Whatever the cause of this elevational shift and of the lower recruitment, mongoose lemurs have an opportunistic feeding strategy and can therefore live in diverse habitats and climates. The transformation of pristine to secondary forest, which has negative consequences for primate health and behaviour (Irwin et al., 2010; Zinner et al., 2014), appears to have had only a minor impact on the grouping patterns of this species, or at least offers a secondary habitat that 
the species can use. The occurrence of large groups in degraded forests confirms that these forests are suitable habitats, possibly because they are rich in fruit, provide more shelter than plantations, and may be used as corridors between the forest and plantations. Variation in resource availability among habitats may be the primary cause of changes in group size, structure and distribution in the species. The smaller group size observed on Anjouan may be linked to the lower availability of resources in the uplands (Rothman et al., 2014), and food limitation may increase the dispersion of males, resulting in a female-biased sex ratio towards the uplands (Merenlender et al., 1998).

There is a widespread perception that lemurs are cropraiding pests, and there is a risk that local people, especially farmers and people from Anjouan, will become intolerant towards the species, mainly because they are rarely compensated for their losses (Regmi et al., 2013). Although many wild species raid crops, primates are perceived as the top pests, possibly because of their visibility (Warren et al., 2007).

Despite the fact that lemurs are considered a threat and are often subject to violence, the majority of the interviewees recognized their value, because their beliefs engender respect for all forms of life, or because they consider lemurs important in the ecosystem or as a tourist attraction. They also recognized the need to protect lemurs, which may be a positive outcome of the educational programmes conducted on Mohéli by the National Marine Park. Although the perception of lemurs as crop raiders is more widespread on Mohéli than on Anjouan, local people showed aggressive attitudes less frequently and there was more widespread awareness of the importance of conservation of the mongoose lemur for human welfare.

Given that the conservation status of E. mongoz is compromised in Madagascar, the Comoros may represent an important pool for the survival of this species. However, it is suffering the consequences of anthropogenic pressures on these islands. Communication of the laws and regulations governing the protection of this species, together with monitoring and enforcement, is needed to prevent the extinction of the remaining population. Establishing terrestrial protected areas will facilitate this process, as will the implementation of educational programmes. Our study showed that educational activities are crucial, but also demonstrated that crop-raiding by lemurs is widespread and has a negative effect on people's food and livelihood security, as it quantitatively and qualitatively reduces food reserves and household incomes. As this is a situation where biodiversity conservation issues and the well-being of local people are correlated, there is an urgent need for more information about the current distribution of the mongoose lemur population. A conservation project is being established on Anjouan, and new surveys are needed to update the status of Eulemur mongoz.

\section{Acknowledgements}

This research was supported by Università degli Studi di Torino and the ACP (African, Caribbean and Pacific Group of States) Science and Technology Programme, with the financial assistance of the European Union, through Projects Gathering Universities for Quality in Education (NFED/2013/320-117), Biodiversity Integration and Rural Development ( $\left.\mathrm{N}^{\circ} \mathrm{FED} / 2009 / 217077\right)$ and Supporting Cooperation for Research and Education), as well as by grants from Parco Natura Viva-Centro Tutela Specie Minacciate. We are grateful to Compagnia di San Paolo for co-financing the Progetto 2008-10 Innovazione Laboratori didattici-Facoltà di Scienze MFN, which facilitated the purchase of equipment used by BN during field activities. We thank all the local people who welcomed and supported BN's field work, and especially the Ramanetaka family (Ouallah). We thank Emilio Balletto for his important contribution to the manuscript, and Dan Chamberlain, Dominic Currie and two anonymous reviewers for constructive comments and editing.

\section{References}

Aкаiкe, H. (1974) A new look at the statistical model identification. IEEE Transactions on Automatic Control, 19, 716-772.

Albers, H.J. \& Ferraro, P. (2006) The economics of terrestrial biodiversity conservation in developing nations. In Economic Development \& Environmental Sustainability: New Policy Options (eds R. López \& M.A. Toman), pp. 382-411. Oxford University Press, New York, USA.

Andriaholinirina, N., Baden, A., Blanco, M., Chikhi, L., Cooke, A., Davies, N. et al. (2014) Eulemur mongoz. In The IUCN Red List of Threatened Species v. 2015.2. Http://www.iucnredlist.org [accessed 21 August 2015].

Bernard, H.R. (2006) Research Methods in Anthropology: Qualitative and Quantitative Approaches, 4th edition. AltaMira Press, Lanham, USA.

Burnham, K.P. \& Anderson, D.R. (2002) Model Selection and Multimodel Inference: A Practical Information-Theoretic Approach. Springer Science \& Business Media, New York, USA.

Díaz, S., Fargione, J., Chapin, III, F.S. \& Tilman, D. (2006) Biodiversity loss threatens human well-being. PLoS Biology, 4(8), e277. ECDD, BCSF \& Durrell (2013) Land Cover Mapping of the Comoros Islands: Methods and Results. Http://www.ecddcomoros. org/wp-content/uploads/2012/o6/ECDD-land-cover-mapping-ofthe-Comoros-final-report-2014.pdf [accessed 24 November 2014].

GANZHORN, J.U. (1994) Lemurs as indicators for habitat change. In Current Primatology: Ecology and Evolution, Volume 1 (eds B. Thierry, J.R. Anderson, J.J. Roeder \& N. Herrenschmidt), pp. 5156. Universitè Louis Pasteur, Strasbourg, France.

Ganzhorn, J.U., Lowry, II, P.P., Schatz, G.E. \& Sommer, S. (2001) The biodiversity of Madagascar: one of the world's hottest hotspots on its way out. Oryx, 35, 346-348.

Irwin, M.T., Johnson, S.E. \& Wright, P.C. (2005) The state of lemur conservation in south-eastern Madagascar: population and habitat assessments for diurnal and cathemeral lemurs using surveys, satellite imagery and GIS. Oryx, 39, 204-218. 
Irwin, M.T., Wright, P.C., Birkinshaw, C., Fisher, B.L., Gardner, C.J., Glos, J. et al. (2010) Patterns of species change in anthropogenically disturbed forests of Madagascar. Biological Conservation, 143, 2351-2362.

MANOR, R. \& SALTZ, D. (2003) Impact of human nuisance disturbance on vigilance and group size of a social ungulate. Ecological Applications, 13, 1830-1834.

Merenlender, A., Kremen, C., Rakotondratsima, M. \& Weiss, A. (1998) Monitoring impacts of natural resource extraction on lemurs of the Masoala Peninsula, Madagascar. Conservation Ecology, 2, 2-5.

Mittermeier, R.A., Louis, E.E., Richardson, M., Schwitzer, C., LANGRAnd, O., Rylands, A.B. et al. (2010) Lemurs of Madagascar, 3rd edition. Conservation International, Washington, DC, USA.

Naeem, S., Duffy, J.E. \& Zavaleta, E. (2012) The functions of biological diversity in an age of extinction. Science, 336, 1401-1406.

Ogada, M.O., Woodroffe, R., Oguge, N.O. \& Frank, L.G. (2003) Limiting depredation by African carnivores: the role of livestock husbandry. Conservation Biology, 17, 1521-1530.

Pastorini, J., Thalmann, U. \& Martin, R.D. (2003) A molecular approach to comparative phylogeography of extant Malagasy lemurs. Proceedings of the National Academy of Sciences of the United States of America, 100, 5879-5884.

R Development Core Team (2013) R: A Language and Environment for Statistical Computing. R Foundation for Statistical Computing, Vienna, Austria.

Regmi, G.R., Nekaris, K.A.I., Kandel, K. \& Nijman, V. (2013) Crop-raiding macaques: predictions, patterns and perceptions from Langtang National Park, Nepal. Endangered Species Research, 20, 217-226.

Reuter, K.E., Gilles, H., Wills, A.R. \& Sewall, B.J. (2014) Live capture and ownership of lemurs in Madagascar: extent and conservation implications. Oryx. Http://dx.doi.org/10.1017/ So03060531400074X [accessed 24 August 2015].

Rothman, J.M., Nkurunungi, J.B., Shannon, B.F. \& Bryer, M.A. H. (2014) High altitude diets: implications for the feeding and nutritional ecology of mountain gorillas. In High Altitude Primates (eds N.B. Grow, S. Gursky-Doyen \& A. Krzton), pp. 247-264. Springer, New York, USA.

Salmona, J., Rasolondraibe, E., Jan, F., Besolo, A., Rakotoarisoa, H., Meyler, S.V. et al. (2014) Conservation status and abundance of the crowned sifaka (Propithecus coronatus). Primate Conservation, 28, 73-83.

Schwitzer, C., Mittermeier, R.A., Johnson, S.E., Donati, G., Irwin, M., Peacock, H. et al. (2014) Averting lemur extinctions amid Madagascar's political crisis. Science, 343, 842-843.

STRUhSAKER, T.T. (1998) A biologist's perspective on the role of sustainable harvest in conservation. Conservation Biology, 12, 930-932.

Tattersall, I. (1976) Group structure and activity rhythm in Lemur mongoz (Primates, Lemuriformes) on Anjouan and Mohéli islands, Comoro Archipelago. Anthropological Papers of the American Museum of Natural History, 53, 367-38o.

Tattersall, I. (1998) Lemurs of the Comoro Archipelago: status of Eulemur mongoz on Mohéli and Anjouan, and of Eulemur fulvus on Mayotte. Lemur News, 3, 15-17.

Warren, Y., Buba, B. \& Ross, C. (2007) Patterns of crop-raiding by wild and domestic animals near Gashaka Gumti National Park, Nigeria. International Journal of Pest Management, 53, 207-216. WorLd BANK (2013) Madagascar: Measuring the Impact of the Political Crisis. Http://www.worldbank.org/en/news/feature/2013/ 06/05/madagascar-measuring-the-impact-of-the-political-crisis [accessed 21 November 2014].

Zinner, D., Wygoda, C., Razafimanantsoa, L., Rasoloarison, R., Andrianandrasana, H.T., Ganzhorn, J.U. \& Torkler, F. (2014) Analysis of deforestation patterns in the central Menabe, Madagascar, between 1973 and 2010. Regional Environmental Change, 14, 157-166.

\section{Biographical sketches}

BAKRI NADHUROU works on the ecology and conservation of lemurs in the Comoros Islands and Madagascar. Roberta Righini is interested in the ecological and anthropogenic factors affecting the distribution of lemurs. MARCo Gamba's research interests include the evolution of animal communication and conservation of primates. PAOLA LAIOLO's research focuses on behavioural, population and community ecology. AHMED OULEDI is involved in coordination and management of development projects in the Indian Ocean, especially in the Comoros Islands. Cristina Giacoma focuses on primate behavioural ecology for the conservation of threatened species. 